\title{
The Effect of Product Review on Purchase Decisions Online on Rananta Store Batam
}

\author{
Yulinda Tarigan*, Ayu Puspitasari, Zulfa Refera, \\ Fandy Bestario Harlan \\ Business Management \\ Politeknik Negeri Batam \\ Batam, Indonesia \\ *yulinda@polibatam.ac.id, ayupuspitasari@polibatam.ac.id, \\ zulfarefera@gmail.com, fandybestario@polibatam.ac.id
}

\author{
Zainal Abidin Tarigan Sirait \\ Economy and Business \\ Universitas Sumatera Utara \\ Medan, Indonesia \\ itszainal@gmail.com
}

\begin{abstract}
The purpose of this study was to determine the effect of product reviews on online purchasing decisions at Rananta store Batam. This type of research is quantitative. Sampling uses a purposive sampling technique The data used are primary data obtained by distributing questionnaires consisting of 12 items / indicator statements regarding product review variables that have sub variables (1) product quality, (2) delivery of goods, (3) price of products and decision variables purchases of 100 respondents who have never and have shopped at Rananta store. The data analysis technique used is multiple linear regression analysis using SPSS version 22 for windows. The results of data analysis indicate that there is an influence of the Online Customer Review on product purchasing decisions. This shows that product reviews greatly affect prospective consumers in making purchasing decisions online, where high positive reviews will cause a sense of confidence for consumers in making purchases. Reviews are very important in the era of digital marketing today because everyone is always looking for and looking at a review before making a decision. Therefore, because of the importance of a product review in a digital marketing it is necessary for Rananta store to have an application that makes it easy for prospective customers to see product reviews before buying. And Rananta store can also expand its shop to get more new buyers who buy based on existing reviews.
\end{abstract}

Keywords-product review, product quality, delivery of goods, product prices, purchasing decisions

\section{INTRODUCTION}

The rapid growth of communication technology is currently affecting changes in consumer behavior from offline purchases to online purchases. Things that influence consumer purchasing decisions online are often found in online consumer reviews, product and service recommendations and the opinions of coworkers who play a role so that they develop into customer decision-making processes [1]. The reason that influences why online shopping is a factor in changing consumer behavior is because it is easy for consumers to find references. Customer review itself is a form of electronic word of mouth (eWOM) that refers to business content posted on an online site or a third party website. A fundamental element of social eWOM is customer-generated content [1].

The main difference between an offline shop \& an online shop is the customer's ability to judge a product offered by a business. In an online shop consumer cannot see or directly touch physically but only assisted with pictures and descriptions provided by the seller, while in the offline shop consumers can immediately see the quality of the product physically. In addition, the online shop payment method usually requires payment via transfer before the goods are delivered to the house, while in the offline shop consumers can usually pay directly with cash. For this reason, online purchases require high trust from consumers before making payments to sellers.

However, of the many conveniences offered from shopping online there are also many factors that cause consumers to not want to shop online, namely the problem of risk. Generally, the problem regarding the risk itself is related to security in payments, fear of fraud, or the quality of goods that are not in accordance with expectations. Consumer complaints are also a factor influencing online purchasing decisions where consumer complaints automatically reduce repurchases from consumers due to their disappointment with the online business concerned. Therefore, the need for an online business to provide a service and product quality in accordance with what is promised with consumers so that there is no disappointment experienced by consumers.

\section{METHODS}

In this study, the population will be customers at Rananta Store starting from 1 December 2019 to 31 December 2019. Based on the data obtained, the average Rananta Store customers each month from January to November amounted to 1,204 customers. This study uses a purposive sampling technique in determining research samples where the number of respondents to be sampled as many as 100 respondents. 
This research is included in quantitative research with a descriptive approach. Quantitative research is a scientific method that is concrete / empirical, objective, measured rationally and systematically [2]. Based on Punaji [3] descriptive research that explains an event or situation related to various variables that can be described using numbers or words. In this study, there are two variables, namely the independent variable (independent variable) and the dependent variable (the dependent variable). In this study the independent variable is the Online Customer Review while the dependent variable in this study is the Purchase Decision (Y). Before conducting the analysis to get a conclusion from the problem there are several stages that must be done. The stage is like the figure 1 below:

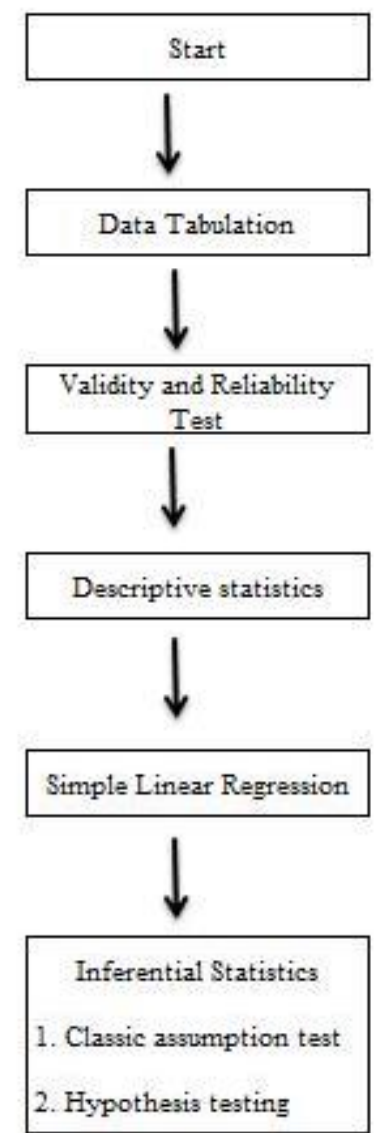

Fig. 1. Data analysis stage.

\section{RESULTS AND DISCUSSION}

\section{A. Descriptive Analysis}

After getting data from respondents who filled out the questionnaire, the results obtained were descriptive analysis research conducted by researchers. The choice of answers contained in the questionnaire includes strongly agree, agree, disagree, and strongly disagree. This can be seen in the continuum line below:

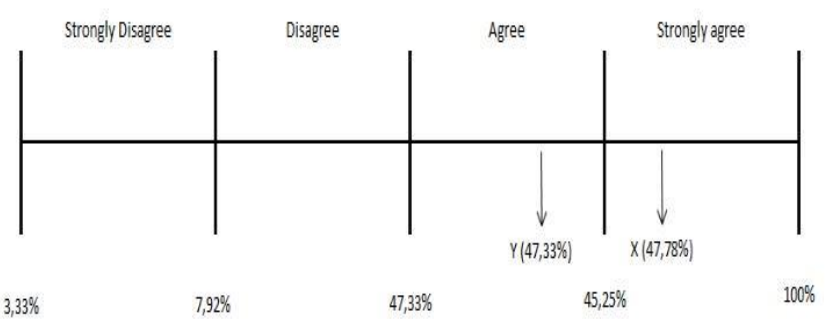

Fig. 2. Continuum line results [4].

Based on the choice of answers in the questionnaire it is known that the highest value is 4 to strongly agree and the lowest value is 1 to strongly disagree. Of the 9 Online Customer Review statements regarding online purchasing decisions surveyed by distributing questionnaires to rananta store customers, overall respondents acknowledged that Online Customer Review influences purchasing decisions with a percentage score of $47.78 \%$ and included in the category of strongly agree. Purchasing decisions that have 3 statements after the survey have a percentage of 47.33 and fall into the agreed category.

\section{B. Simple Linear Regression Analysis}

\begin{tabular}{|c|c|c|c|c|c|}
\hline \multicolumn{6}{|c|}{ Coefficients $^{a}$} \\
\hline \multirow[t]{2}{*}{ Model } & \multicolumn{2}{|c|}{$\begin{array}{c}\text { Unstandardized } \\
\text { Coefficients }\end{array}$} & \multirow{2}{*}{$\begin{array}{c}\begin{array}{c}\text { Standardized } \\
\text { Coefficients }\end{array} \\
\text { Beta }\end{array}$} & \multirow[t]{2}{*}{$t$} & \multirow[t]{2}{*}{ Sig. } \\
\hline & B & Std. Error & & & \\
\hline (Constant) &, 927 & 635 & & 1,459 & 148 \\
\hline $\begin{array}{c}1 \text { Online Costumer Review } \\
\text { (X) }\end{array}$ & ,307 &, 021 & 831 & 14,762 & 000 \\
\hline
\end{tabular}

Fig. 3. Result of simple regression analysis [4]

Based on the results of data processing using SPSS, a constant coefficient value of 0.927 is obtained, which means that if there is no Online Customer Review (X) then the consistent value of online purchasing decisions is 0.927 . Because the value of the regression coefficient value $(+)$, then it can be said that the Online Customer Review (Product Review) (X) has a positive effect on online purchasing decisions. So the regression equation is $\mathrm{Y}=0.927+0.307 \mathrm{X}$.

\section{T Test}

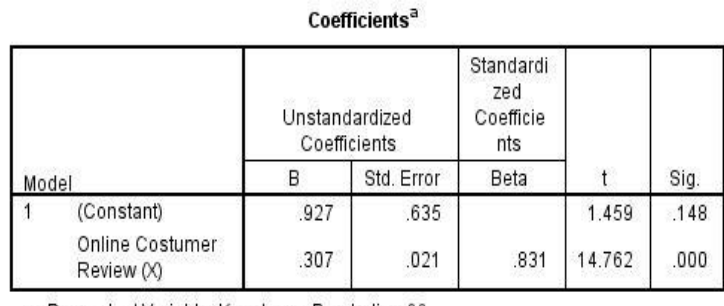

a. Dependent Variable: Keputusan Pembelian $(Y)$

Fig. 4. Result of T- Test [4]. 
Testing the hypothesis of customer reviews online variables against purchasing decisions:

- $\mathrm{H}_{0}$ : there is an influence of the Online Customer Review on product purchasing decisions.

- $\mathrm{H}_{\mathrm{a}}$ : there is no effect of the Online Customer Review on online purchasing decisions.

Based on the SPSS output table "Coefficients" above it is known the significance value (Sig) of online customer review $(\mathrm{X})$ variables is equal to 0,000 . Because the value of Sig. 0,000 $<0.05$, so it can be concluded that Ho was accepted and Ha was rejected. Which means that there is an influence of the Online Customer Review on product purchasing decisions.

\section{Coefficient of Determination}

\begin{tabular}{|c|c|c|c|c|}
\hline \multicolumn{5}{|c|}{ Model Summary } \\
\hline Model & $R$ & R Square & Adjusted R Square & $\begin{array}{c}\text { Std. Error of the } \\
\text { Estimate }\end{array}$ \\
\hline 1 & $.831^{3}$ & 690 & 687 & 983 \\
\hline
\end{tabular}

Fig. 5. Result of coefficient determination [4].

Based on the above data, a coefficient of determination (R2) of 0.690 or $69 \%$ is obtained. This shows that $69 \%$ of purchasing decisions at rananta store are influenced by the Online Customer Review variable. While $31 \%$ is influenced by other variables not included in this research model.

\section{E. Discussion}

Based on the results of the analysis of respondents it can be seen that the majority of respondents who shop at rananta stores are aged 30-40 years with a number of respondents 53 (53\%), and respondents who shop at rananta stores mostly earn Rp. 2000,000 - Rp. 3,500,000 with the amount 40 respondents (40\%), as well as respondents who made purchases at the Rananta store mostly use Instagram as online media with 46 respondents $(46 \%)$.

Based on the questionnaire that has been distributed to respondents whether the respondent reads the reviews of other people before buying at the store, most of them answered YES with a total of $89(89 \%)$ and those who answered NO 11 $(11 \%)$. This explains that in the store customer reviews greatly affect prospective buyers before making a decision in making a purchase. The average consumer will first read a review that has been there, because of the importance of a review itself where if the review for rananta store has been positive and previous buyers have also done a lot of repeat orders then it will further convince potential buyers to make purchases at rananta store.

This is in line with research conducted by Holleschovsky and Constantinides [1] which states that the reason for seeking product reviews depends on the behavior and different views of each person on the characteristics of the review. Based on this, it can be concluded that product reviews greatly affect potential consumers in making online purchasing decisions, where high positive reviews will create a sense of confidence for consumers in making purchases.

Based on the results of the study showed that product reviews have a positive effect on online purchasing decisions, this is evidenced by the fcount of 14.762> $t$ table 1.984. This shows that respondents are concerned to read product reviews first before making a decision to make an online purchase. Of the three product review sub-variables that received the lowest value with a value below the average value of the whole statement, namely the delivery of goods. That is because the estimated delivery of goods is sometimes not in accordance with the estimates. Whereas of the three product review subvariables that have the highest value with a value that is above the average value of the whole statement that is product quality. That is because the standard of the quality of the product promised is in accordance with what is offered. Of the three product review sub-variables does not mean that the price of the product does not affect consumers in making decisions, it's just that the price of the product returns to each prospective customer, if they read the review and it turns out the results of the review are good but the price is not suitable for the prospective customer, then that could be the reason why buyers don't make purchases.

This is in line with research conducted by Ichsan, Jumhur, and Dharmoputra [4] which states that the influence of consumer online rating and review has a significant influence on consumer buying interest and can carry out its functions properly. Based on this it can be concluded that from product reviews prospective consumers can be affected in making purchasing decisions, where the most prominent sub-variable is product quality.

\section{CONCLUSION}

Based on the results of data analysis obtained from 100 respondents who have been described in the analysis of the data contained in the previous chapter, where this study aims to determine the effect of Product Review on Online Purchasing Decisions at Rananta Store. Then the following conclusions are drawn:

- Based on the results of the previously distributed questionnaire, the customer review on Rananta Store has influenced potential buyers in making purchasing decisions. The reason lies in the fact that in searching for customer reviews, it depends on the behavior and frequency of consumer purchases.

- According to the results of research conducted by product review researchers have a positive effect on purchasing decisions. The reason is evidenced by the $t$ test carried out in the previous chapter where fcount is $14.762>\mathrm{ft}$. 1.984. This states that the coefficients of the fcount are greater than the ftabel value. 
- variable questionnaire, the product quality sub-variable gets the highest value that is above the average of the overall statement. That is because the standard quality of products from the promising store and products in accordance with those offered.

- Based on the results of the product review variable questionnaire, the delivery of goods sub-variable gets the lowest value below the average of the whole statement. That is because the estimated shipping of goods that is not in accordance with the supposed estimation.

- Based on the results of the product review variable questionnaire, the product price sub-variable gets the average value of the whole statement. Where for the price of the product all returned to each prospective consumer. If after reading the review and it turns out that the review itself is good but for the price that does not match it can be the reason why potential customers do not make a purchase.

\section{REFERENCES}

[1] N.I. Holleschovsky and E. Constantinides, "Impact of online product reviews on purchasing decisions," Research Gate, 2016.

[2] Sugiyono, Statistik Untuk Penelitian. Bandung: Alfabeta, 2010.

[3] S. Punaji, Metode Penelitian dan Pengembangan, 2013.

[4] M. Ichsan, H.M. Jumhur, and S. Dharmoputra, "Pengaruh Consume Online Rating And Review Terhadap Minat Beli Konsumen Pada Marketplace Tokopedia Di Wilayah Dki Jakarta," eProceedings of Management, vol. 5, no. 2, 2018. 